DOI 10.18413/2687-0967-2020-47-1-21-29

\title{
К ИСТОРИИ ИЗУЧЕНИЯ МОНЕТНОГО ДЕЛА ЦАРЯ АСАНДРА
}

\section{ON THE HISTORY OF THE STUDY OF THE COINAGE OF KING ASANDER}

\author{
M.M. Чореф \\ M.M. Choref \\ Нижегородский государственный университет им. Н.И. Лобачевского, \\ Россия, 603950, г. Нижний Новгород, ул. Гагарина, 23 \\ Lobachevsky State University of Nizhni Novgorod, \\ 23 Gagarin Avenue, Nizhnij Novgorod, 603950, Russia \\ E-mail: choref@yandex.ru
}

\begin{abstract}
Аннотация
Наше внимание привлекли две монеты, отнесенные В.А. Анохиным к выпускам царя Асандра: золотая, на реверсе которой исследователь разобрал «ВА I $\Lambda \Delta \Omega \Sigma$ A $\Sigma$ ANГPOT ВО $\Sigma \Pi О Р О T »$, и

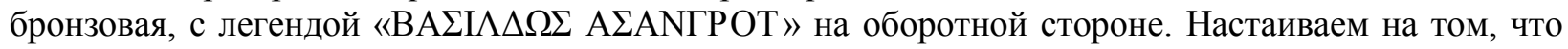
их атрибуции, приведенные исследователем, безосновательные и ошибочные. Первая из этих монет явно новодельная, причем фантазийная. Полагаем, что ее изготовили в Новое время для доверчивых коллекционеров. Причем на ней отсутствует легенда, которую привел В.А. Анохин. Подчеркнем, что текст «ВА $\Sigma \mathrm{I} \Lambda \Delta \Omega \Sigma$ А $\Sigma$ АNГРОТ ВО $\Sigma$ ПОРОТ» вряд ли мог появиться на боспорской монете. Немаловажно и то, что опубликованное исследователем фото этого артефакта несет следы основательного ретуширования. Приведенная им надпись неразличима. Вторая монета, безусловно, подлинная, но нет оснований для отнесения ее к боспорскому чекану. Однотипные монеты известны уже не первое столетие. Речь идет об ординарных дилептонах сирийского царя Александра I Бала.
\end{abstract}

\begin{abstract}
Our attention was attracted by two coins attributed by V.A. Anokhin to the issues of King Asander: gold, on the reverse of which the researcher took apart «BA $\Sigma \mathrm{I} \Lambda \Delta \Omega \Sigma$ А $\Sigma$ ANГРОТ ВО $\Sigma \Pi О Р О T »$ and bronze, with the legend «BA $\Sigma \mathrm{I} \Lambda \Delta \Omega \Sigma \mathrm{A} \Sigma \mathrm{AN} \Gamma \mathrm{POT} »$ on the flip side. We insist that their attributions given by the researcher are baseless and erroneous. The first of these coins is clearly remakeable, and fantasy. We believe that it was made in modern times for gullible collectors. Moreover, there is no legend on it that

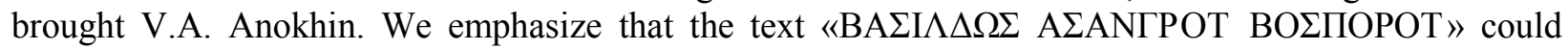
hardly have appeared on the Bosporus coin. It is also important that the photo published by the researcher of this artifact bears traces of thorough retouching. The inscription given by him is indistinguishable. The second coin is certainly genuine. But there is no reason to attribute it to the Bosporus coinage. Coins of the same type have been known for more than a century. They see the ordinary dileptons of the Syrian king Alexander I Balas.
\end{abstract}

Ключевые слова: история, нумизматика, Боспор, Сирийское царство, новодельные монеты. Key words: history, numismatics, Bosporus, Syrian kingdom, restrike.

Уже не первое поколение историков уделяет внимание изучению нумизматики Боспора эпохи правления Асандра ${ }^{4}$ (48/47-19/18 гг. до н. э.). И это не случайно. Его монеты являются ценнейшими источниками исторической информации [Анохин, 1986, c. 77-80; Анохин, 1999, с. 119-120; Фролова, 1997a, с. 14-23, 165-177; Фролова, 2001,

\footnotetext{
${ }^{4}$ Так, статеры Асандра издали Ф. де Кари [Cary, 1752, p. 35, 36, pl. I, 4, 5] и М. Гатри [Guthrie, 1802, No. 4, 5].
} 
c. 17-60; Чореф, 2014, с. 456-487; Чореф, 2016, с. 119-124]. Однако процесс их изучения все еще далек от завершения. До сих пор идет дискуссия по вопросу атрибуции ряда выпусков этого государя. Продолжая изучение монетного дела Асандра [Чореф, 2014, с. 456-487; Чореф, 2016, с. 119-124], перейдем к золотой и бронзовой монетам, изображения ${ }^{5}$ которых приведены на рис. 1. Их ввел в научный оборот В.А. Анохин [Анохин, 1986, № 246; Анохин, 2011, № 1318, 1342]. Приводим их описание, представленное ученым в его фундаментальном каталоге «Античные монеты Северного Причерноморья»:

1318. Л. с. Голова в диадеме вправо.

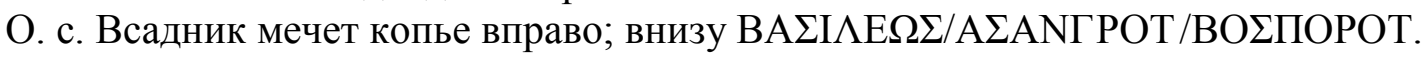
Золото. Статер.

8,50 г.

Ч. к.

1342. Л. с. Голова Гелиоса анфас.

О. с. ВА I $\Lambda \Delta \Omega \Sigma / \mathrm{A} \Sigma \mathrm{AN} Г$ РОТ. Пегас вправо; внизу - Г (4 год?).

Медь.

2,12 г.

SNG Fitzwilliam 1604.

Сразу же заметим, что приведенное В.А. Анохиным описание золотого (рис. 1,1 ) нельзя признать точным. Нумизмат не акцентировал внимание читателя на том очевидном факте, что этот артефакт представляет собой подвеску с массивным золотым ушком. Этим обстоятельством следует объяснять его неординарно большой вес. Напомним, что статеры Асандра чеканили по стопе ок. 8,25 г [Анохин, 1986, с. 146-147; Фролова, 1997a, c. 165-174; Фролова, 2001, с. 18-27]. Кроме того, исследователь не отметил тот факт, что, судя по опубликованному им изображению, на лицевой стороне золотого просматривается одна из лент диадемы, которая развевается у затылка. Этот элемент оформления аверса характерен для золота царя Асандра [Анохин, 1986, табл. 9, 228-239, 10, 240-245; Анохин, 1999, рис. 29, 6; Анохин, 2011, № 1319-1341; Фролова, 1997а, табл. Іа, 5 - IIIа, 1-8; Фролова, 2001, табл. Іа, 5 - III, 1-4].

Мы вынуждены обратить внимание читателя и на следующее, с нашей точки зрения, весьма досадное обстоятельство. Дело в том, что фотографии артефактов подвергли ретушированию. Хорошо видно, что буквы легенд реверса обведены белыми линиями (рис. 1). Причем эту операцию проделал один и тот же человек. Судим по написанию

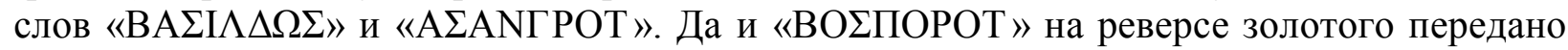

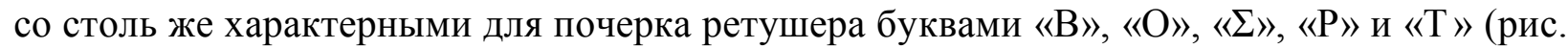
1). Однако бронзовая монета была опубликована в 1986 г. [Анохин, 1986, № 246], а золотая - только в 2011 г. [Анохин, 2011, № 1318]. Полагаем, что этот факт весьма немаловажен.

Действительно, заинтересовавшие В.А. Анохина монеты, судя по изображениям лицевой и оборотной сторон, сильно изношены. Однако ретуширование фотографий не дает оснований считать их качественным воспроизведением изображений изучаемых древностей. Куда целесообразнее было бы добавить их прориси. Но такова была воля исследователя.

Учитывая сложившиеся обстоятельства, ставим перед собой цель проверить атрибуцию артефактов, опубликованных В.А. Анохиным. Для этого попытаемся найти качественные изображения их или подобных им предметов.

\footnotetext{
${ }^{5}$ Опубликованы В.А. Анохиным [Анохин, 1986, № 246; Анохин, 2011, № 1318, 1342].
} 
И они имеются. Сравнительно недавно на сайте «Монеты Боспора» появилось краткое сообщение о первом из интересующих нас артефактов ${ }^{6}$ (Монета: 232-4473). Оно снабжено высококачественной фотографией (рис. 2, 1). Согласно сообщению, артефакт в настоящее время хранится в коллекции Ю.Л. Покрасса. Есть все основания полагать, что речь должна идти о том самом золотом, который в 2011 г. издал В.А. Анохин. И авторы сообщения информируют об этом читателей. Приведем подробное описание этого артефакта.

На его лицевой стороне отчеканен весьма грубо исполненный бюст безбородого мужчины вправо. Вряд ли есть основания считать его портретным. Однако допустим, что резчик штемпеля все же смог передать самые заметные черты лица изображенного. Так, стоит обратить внимание на нависший над глазами непропорционально массивный, гротескный лоб, на массивный нос и на губы, переданные двумя толстыми короткими линиями, а также на тяжелый волевой подбородок.

Что касается развевающейся ленты диадемы, то она, хорошо заметная на иллюстрации в каталоге «Античные монеты Северного Причерноморья» [Анохин, 2011, № 1318], на качественном фото едва различима. Похоже, что мы имеем дело с очередным случаем ретуши. Зато просматривается другая, ниспадающая лента диадемы. Ее конец просматривается под шеей бюста (рис. 2, 1). Заметим, что этот элемент оформления характерен для золотых Асандра [Анохин, 1986, табл. 9, 228-239, 10, 240-245; Анохин, 1999, рис. 29, 6; Анохин, 2011, № 1319-1341; Фролова, 1997а, табл. Іа, 5 - IIІа, 1-8; Фролова, 2001, табл. Іа, 5 - III, 1-4].

Куда сложнее определить, что за прическа у изображенного. Складывается впечатление, что его голову обрамляет высокий и широкий валик. Неслучайно он так рельефен. Может даже показаться, что на голове мужчины шляпа. Но вряд ли это так. Вполне возможно, что резчик штемпеля пытался повторить бюст с завитыми концами прядей, украшающий статеры Асандра ${ }^{7}$ [Анохин, 1986, табл. 9, 228-239, 10, 240-245; Анохин, 1999, рис. 29, 6; Анохин, 2011, № 1319-1341; Фролова, 1997a, табл. Іа, 5 - IIІа, 1-8; Фролова, 2001, табл. Іа, 5 - III, 1-4] (рис. 2, 2). Правда, они не напоминают поля шляпы. Так что резчик штемпеля или не был профессионалом, или не отдавал себе отчет в том, что копировал.

В любом случае ясно, что лицевая сторона артефакта не могла быть отчеканена при Асандре. Ведь на аверсе его золотых выбивали идеализированный бюст правителя. Вполне возможно, что его трактовали как ипостась Мена-Фарнака [Чореф, 2012, с. 47]. А на лицевой стороне изучаемого артефакта, как уже было отмечено выше, отчеканено грубое, можно даже сказать гротескное изображение.

Не менее примечателен и реверс. На нем различима фигура скачущего вправо всадника. Под ней была отчеканена трехстрочная надпись. Разобрать ее не представляется возможным. Мы в очередной раз вынуждены констатировать неуместность ретуширования, результаты которого были приведены В.А. Анохиным [Анохин, 2011, № 1318$]$.

Перейдем к изучению выявленных элементов оформления реверса. Начнем с того, что на бесспорно атрибутируемых выпусках боспорского золота неизвестны изображения скачущего всадника [Анохин, 1986; Анохин, 1999; Анохин, 2011; Фролова, 1997a; Фролова, 1997b; Фролова, 2001]. Однако схожая композиция характерна для драхм Гигиэнонта ${ }^{8}$ [Анохин, 2011, № 1276; Чореф, 2017, с. 62, рис. 1, 2, 3]. Правда, на них всадник скачет влево. Но куда важнее то, что на этих монетах легенда

\footnotetext{
${ }^{6}$ К сожалению, размеры монеты не указаны. Не привел их и В.А. Анохин [Анохин, 2011, № 1318].

${ }^{7}$ На рис. 2, 2 приведена фотография статера Асандра; находится в коллекции Staatliche Museen zu Berlin [Фролова, 2001, с. 22, табл. Іа, 12].

${ }^{8}$ Приведено изображение одной из таких монет, опубликованное в [Чореф, 2017, с. 62, рис. 1, 2 ].
} 


\section{«APYON $\Sigma \mathrm{O} \Sigma$ TГIAINON $\Sigma \mathrm{O} \Sigma$ р размещена под композицией реверса}

(рис. 2, 3).

Заметим, что куда более схожее изображение всадника, причем скачущего не влево, а вправо, известно на сестерциях ${ }^{9}$ Рескупорида I (69-91/92 гг.) (рис. 2, 4). Примечательно и то, что на лицевой стороне этих монет выбит портрет правителя со столь же рельефным, широким и изогнутым обрамлением головы из завитых концов прядей волос. Следует обратить внимание и на то, что у Рескупорида I на монете крупные черты лица: массивный, правда, не до гротескности, лоб, большой нос, а губы переданы двумя короткими тонкими линями (рис. 2, 4).

Основываясь на выявленных фактах, заключаем, что на аверсе золотого, изданного В.А. Анохиным, отчеканена непрофессионально выполненная копия бюста Рескупорида I, известная на монетах его чекана. А на реверсе объекта нашего изучения размещена фигура скачущего вправо всадника, характерная для сестерциев вышеупомянутого государя, ниже которой, как на драхмах Гигиэнонта, выбита трехстрочная надпись.

Подчеркнем, что оформленные в таком духе золотые монеты чекана Асандра, равно как и прочих правителей Боспора, не известны [Анохин, 1986; Анохин, 1999; Анохин, 2011, № 1267-2203; Фролова, 1997a; Фролова, 1997b; Фролова, 2001, с. 17-60]. Это дает нам основание видеть в артефакте, опубликованном В.А. Анохиным, новодел, причем фантазийный, изготовленный для доверчивых коллекционеров.

Перейдем к бронзовой монете на рис. 1, 2. В.А. Анохин писал, что ее изображение издано в SNG Fitzwilliam [Meadows, Purefoy, Robinson, 1972, p. 1604]. И это так. На рис. 3, 1 приводим фотографию этой монеты из цитируемого исследователем издания. Однако по фотографии в SNG Fitzwilliam на реверсе бронзы читается только верхняя строка, в которой, действительно, различимо слово «ВА I $\Lambda \Delta \Omega \Sigma »$. В то же время имя правителя на монете разобрать не представляется возможным. Мы вынуждены в очередной раз констатировать факт неуместности ретуши.

Но куда важнее следующее обстоятельство. Составители SNG Fitzwilliam не были склонны отнести эту монету к выпускам Асандра. Они действительно полагали, что ее выпустили на Боспоре. Но ученые допустили, что эту монету следует датировать правлением Митридата VIII(III) (39-44 гг. н. э.) ${ }^{10}$. И этот вывод вполне объясним. Ведь на реверсе описанной учеными бронзы оттиснута фигура пегаса, характерная для ранних серий серебра Митридата VI Евпатора Диониса, поступавших в обращение до 86/85 г. до н. э. [Сапрыкин, 1996, с. 173; Сапрыкин, 2009, с. 138-139; Чоpeф, 2016, c. 539; de Callatä̈, 1997, pl. I, D1-Rla-D5-Rla, II-VII, D65-Rla-D69$R l a, \mathrm{XIV}, D 1-R l a-D 4-R 1 b, D 3-R 1 b, A, C-F]$, а также для бронз понтийских городов периода его правления [Сапрыкин, 2009, с. 133-134; de Callatä̈, 1997, pl. XLVIII, I, J]. В то же время на ее лицевой стороне отчеканена эгида, не известная на выпусках этого государя. Так что есть основания считать, что монету выпустили при правителе, попытавшемся продолжить дело великого врага Рима, причем чеканившего именные бронзы. Кандидатура Митридата VIII(III) напрашивается здесь сама собой.

Однако этот вывод все же следует пересмотреть. Дело в том, что хорошо известны однотипные бронзы ${ }^{11}$ (рис. $3,2-8$ ), причем с полностью или с частично читающейся нижней строкой легенды реверса. На их оборотной стороне отчеканено

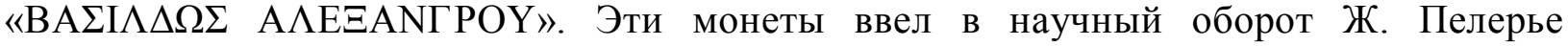

\footnotetext{
${ }^{9}$ Монета, изображение которой приведено на рис. 2, 4, хранится в собрании Museum of Fine Arts, Boston (Inv. No. 64.2163).

10 SNG. No. SNGuk_0402_1604. URL: http://www.sylloge-nummorum-graecorum.org/ (дата обращения: 10.08.2019).

${ }^{11}$ Первые две монеты изданы Ж. Пелерье (рис. 3, 2), Ж. Бабелоном (рис. 3, 3). Они находятся в коллекции Bibliothèque nationale de France (рис. 3, 4, 8). Остальные бронзы хранятся в собрания American Numismatic Society (рис. 3, 6, 7) и Bibliothèque nationale de France (рис. 3, 5, 8).
} 
[Pellerin, 1762, pl. X]. Ученый заключил, что они были выпущены при Александре I Теопаторе Эвергете (Бале) (150-145 гг. до н. э.), уроженце Смирны, самозваном сыне Антиоха IV Эпифана (175-164 гг. до н. э.), узурпировавшем на время трон государства Селевкидов. Его точку зрения принял Й.Х. Эккель [Eckhel, 1828, p. 228]. К тому же выводу пришел и Ж. Бабелон [Babelon, 1936a No. 3355; Babelon, 1936b, pl. CXXIII, 3355].

Привлекшие наше внимание бронзы оформлены следующим образом:

Л. с. Эгида с горгонейоном в центре.

O. с. ВА $\Sigma \Lambda \Lambda \Omega \Sigma$ A $\Lambda$ EАNГPOY в две строки. Они размещены в верхней и в нижней частях поля реверса. Между ними отчеканена фигура Пегаса, скачущего вправо. Между ног животного выбита монограмма A

К настоящему времени известно две их разновидности. Они различаются оформлением аверса. На лицевой стороне монеты, опубликованной в SNG Fitzwilliam, оттиснута прямоугольная эгида (рис. 3, 1). Аналогичным образом оформлен аверс бронз на рис. 3, 2, 4-6. А на монетах на рис. 3, 3, 7, 8 она квадратная.

Но не это самое важное. Куда существеннее то, что эти бронзы, судя по легенде реверса, отчеканили не при Асандре, а при Александре. А гипотетическая буква «Г», в которой В.А. Анохин видел обозначение даты выпуска, которые, к слову, не известны на монетах Боспора, является монограммой А. Заметим, что ее не удалось выявить на деньгах этого государства. Так что у нас нет никаких оснований считать изучаемую бронзу боспорской.

Перейдем к выводам. Очевидно, что монеты на рис. 1 не могли быть отчеканены на Боспоре в период царствования Асандра. Причем первая из них, золотая (рис. 3,1 ), вряд ли является античной. Вернее всего, она представляет собой фантазийный новодел. Что же касается второй, бронзовой, то она была отчеканена в государстве Селевкидов.

Что же могло побудить В.А. Анохина отнести их к официальному чекану Боспора? Этот вопрос останется открытым. Заметим лишь, что не видим оснований подозревать ученого в низкой профессиональной подготовке. Настаиваем на том, что его ввели в заблуждение недобросовестные информаторы. Вполне возможно, что В.А. Анохин не был непосредственно знаком с цитируемым им каталогом SNG Fitzwilliam. Это допущение позволяет объяснить тот факт, что исследователь привел фотографию интересующей его монеты с ретушью.

Вполне возможно, что ученый получил описания этих двух монет, снабженных ретушированными фотографиями, в период работы над своей монографией «Монетное дело Боспора». Его внимание привлекла бронза. Действительно, вопроса о ее подлинности не возникает. Куда позже, на склоне лет, он пришел к выводу, что и золотая монета является аутентичной. И сведения о ней появились в «Античных монетах Северного Причерноморья». Причем вряд ли его информатором являлся нынешний владелец монеты. Ведь он мог бы предоставить не отретушированное, а качественное цветное фото. Но это, повторимся, только наше допущение. Очевидно лишь одно. Фотографии, опубликованные B.А. Анохиным, не соответствуют внешнему виду артефактов. И их не могли отчеканить при Асандре.

Выносим результаты нашего исследования на научное обсуждение. 

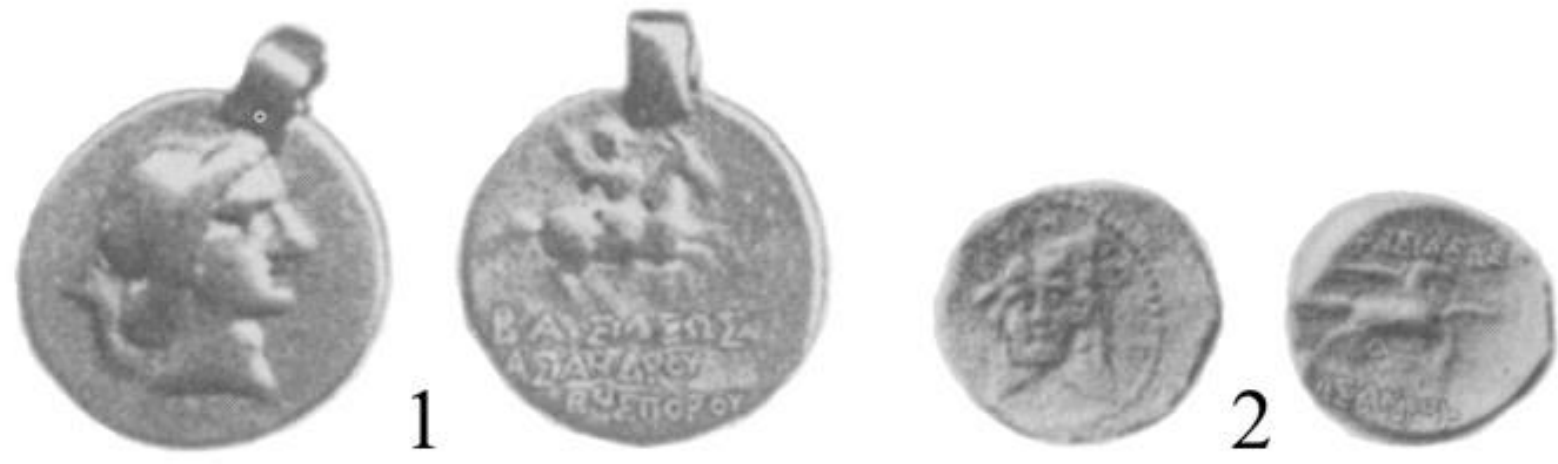

Рис. 1. Золотая и бронзовая монеты, отнесенные В.А. Анохиным к выпуску царя Асандра Fig. 1. Gold and bronze coins attributed by V.A. Anokhin to the release of King Asander
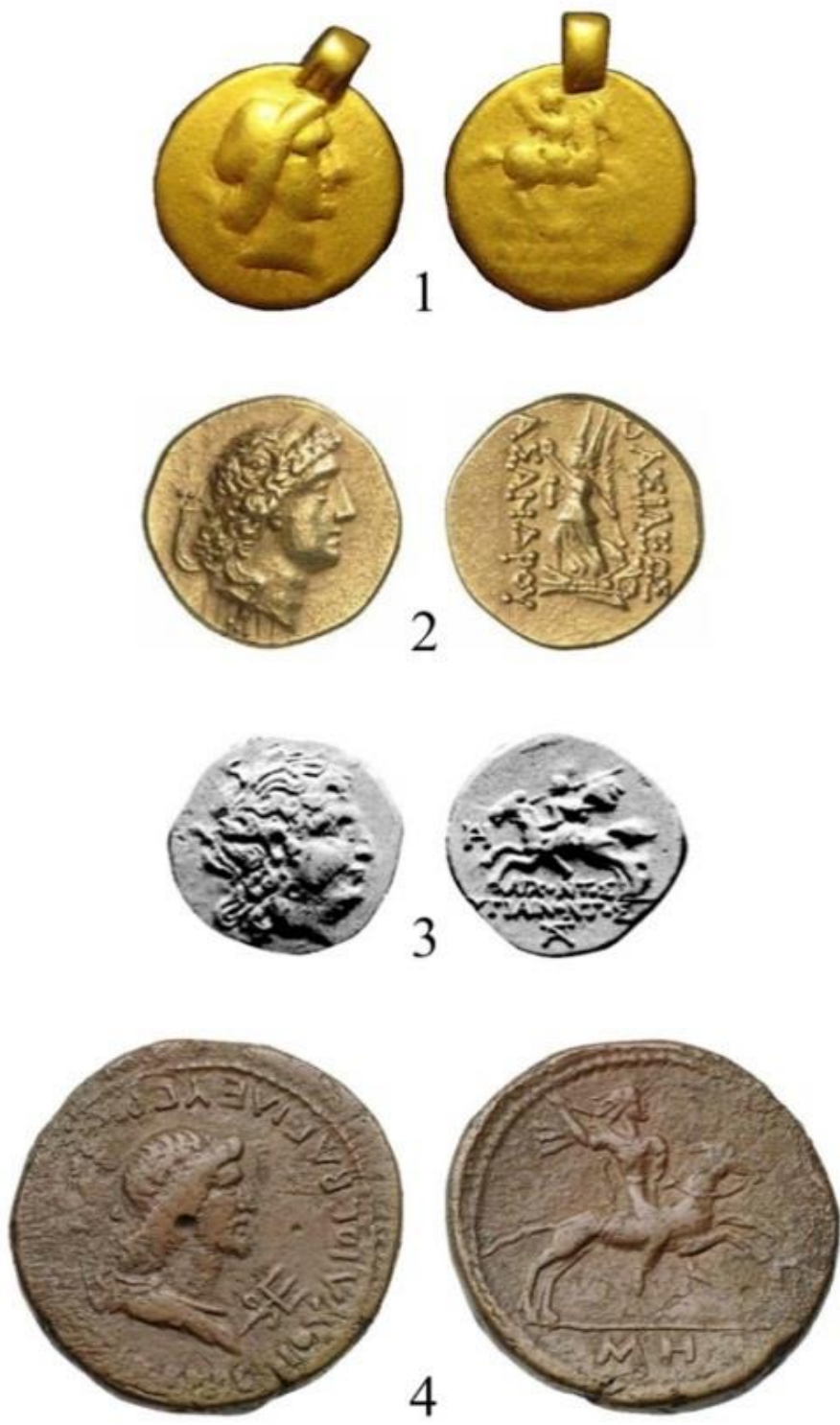

Рис. 2. К атрибуции золотой монеты: 1 - ее качественное фото; 2 - статер Асандра; 3 - драхма Гигиэнонта, 4 - сестерций Рескупорида I

Fig. 2. To the attribution of a gold coin: 1 - its high-quality photo; 2 - stater of Asander; 3 - drachma of Hygiainon, 4 - sestertius of Reskuporid I 

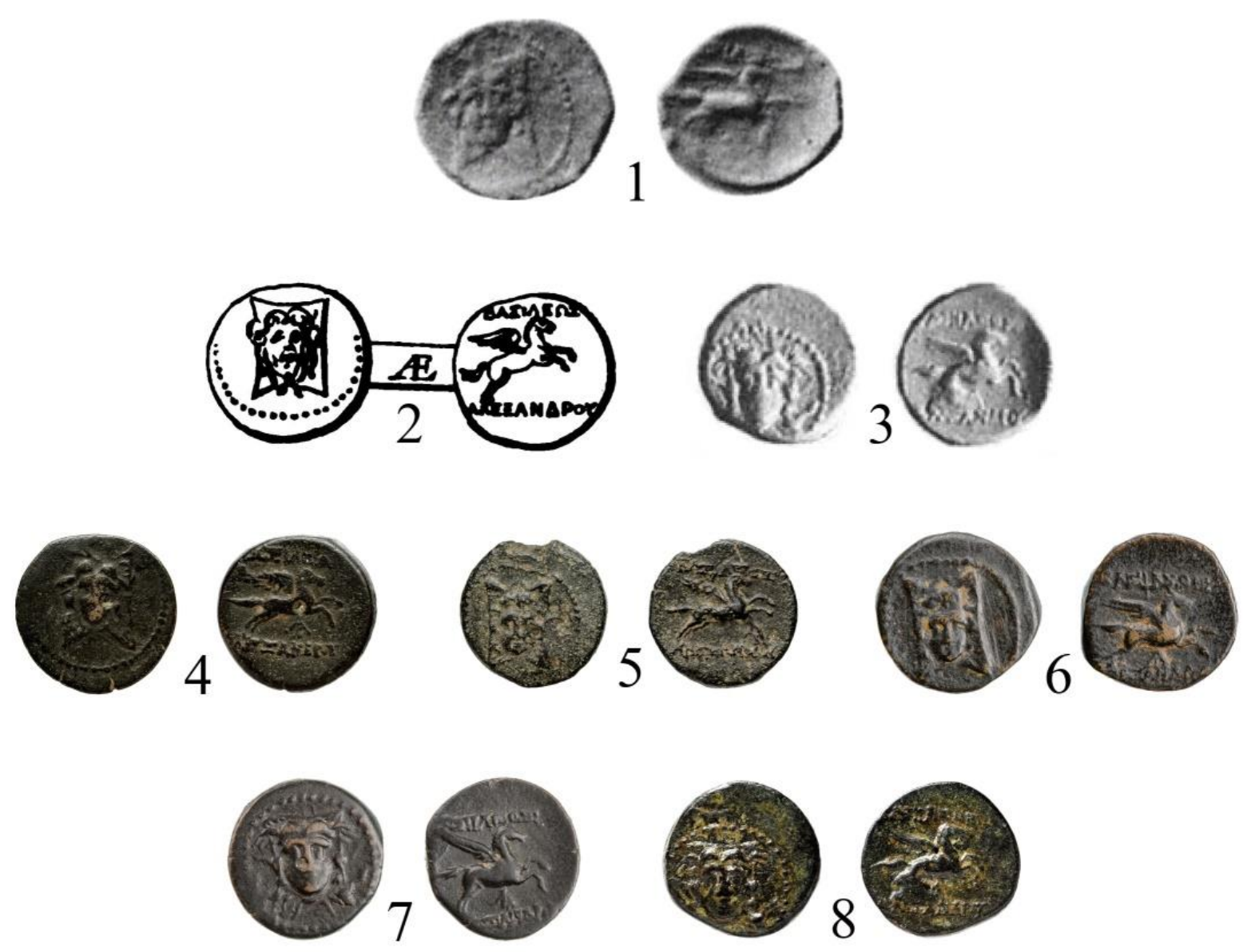

Рис. 3. К атрибуции бронзовой монеты: 1 - ее фотография из SNG Fitzwilliam; 2 - рисунок, изданный

Ж. Пелерье; 3 - фотография монеты из «Catalogue de la collection de Luynes. Monnaies grecques» Ж. Бабелона; 4-8 - фотографии монет этого типа из собраний American Numismatic Society и Bibliothèque nationale de France

Fig. 3. To the attribution of a bronze coin: 1 - her photo from Fitzwilliam SNG; 2 - a drawing published by J. Pelerier; 3 - is a photograph of a coin from the «Catalog de la collection de Luynes. Monnaies grecques» by J. Babelon; 4-8 are photographs of coins of this type from the collections of the American Numismatic

Society and the Bibliothèque nationale de France

\section{Список литературы}

1. Анохин В.А. 1986. Монетное дело Боспора. Киев, Наукова думка. 183.

2. Анохин В.А. 1999. История Боспора Киммерийского. Киев, Одигитрия. 240.

3. Анохин В.А. 2011. Античные монеты Северного Причерноморья. Киев, Стилос. 328.

4. Монета: 232-4473. URL: https://bosporan-kingdom.com/000-4770/1.html (дата обращения: 10.08.2019)

5. Сапрыкин С.Ю. 1996. Понтийское царство. Государство греков и варваров в Причерноморье. М., Наука. 430.

6. Сапрыкин С.Ю. 2009. Религии и культы Понта эллинистического и римского времени. М., Тула, Триумф принт. 430.

7. Фролова Н.А. 1997а. Монетное дело Боспора (середина I в. до н. э. - середина IV в. н. э.). Ч. І. Монетное дело Боспора 49/48 гг. до н. э. - 210/211 гг. н. э. М., Эдиториал УРСС. 448.

8. Фролова Н.А. 1997b. Монетное дело Боспора (середина I в. до н. э. - середина IV в. н. э.). Ч. ІІ. Монетное дело Боспора 211-341/341 гг. н. э. М., Эдиториал УРСС. 536.

9. Фролова Н.А. 2001. Боспорские монеты времени правления Асандра (49/48-21/20 гг. до н. э.). В кн.: Труды Государственного исторического музея. Вып. 115. Нумизматический сборник. Ч. XIV. Нумизматика в Историческом музее. М., ГИМ: 17-60. 
10. Чореф M.M. 2012. «Calamitas virtutis occasio», или к истории последних лет царствования Фарнака II. Научные ведомости Белгородского государственного университета. № 7(126). Вып. 22: 44-59.

11. Чореф М.М. 2014. К биографии Асандра: путь к престолу. Материалы по археологии и истории античного и средневекового Крыма. Вып. 6: 456-487.

12. Чореф М.М. 2016. К вопросу о дешифровке монограмм на боспорских монетах Митридата VI Евпатора Диониса. Материалы по археологии и истории античного и средневекового Крыма. Вып. 8: 523-562.

13. Чореф М.М. 2017. К истории правления архонта Гигиэнонта. Вестник Нижегородского университета им. Н.И. Лобачевского. 6: 62-72.

14. Babelon J. 1936a. Catalogue de la collection de Luynes. Monnaies grecques. Vol. IV. Syrie, Egypte, Cyrénaïque, Maurétanie, Zeugitane, Numidie. Paris, J. Florange, L. Ciani, 152.

15. Babelon J. 1936b. Catalogue de la collection de Luynes. Monnaies grecques. Vol. IV. Syrie, Egypte, Cyrénaïque, Maurétanie, Zeugitane, Numidie. Planches. Paris, J. Florange, L. Ciani, 76.

16. Cary F. 1752. Histoire des rois de Thrace et de ceux du Bosphore cimmérien éclaircie par les médailles. Paris, Ches Desaint \& Saillantm, 212.

17. de Callataÿ F. 1997. L'histoire des guerres mithridatiques vue par les monnaies. Publications d'Histoire de 1'Art et d'Archéologie de 1'Université Catholique de Louvan XCVIII. Numismatica Lovaniensia 18. Louvain-la-Neuve, Département d'Archéologie et d'Histoire de 1'Art, Séminaire de numismatique Marcel Hoc, 312.

18. Eckhel I. 1828. Doctrina numorum veterum. Vol. III. Continens Reliqvam Asiam Minorem, Et Regiones Deinceps In Ortvm Sitas. Pt. I. De numis urbium, populorum, regum. Vindobona: Sumptibus Friderici Volke, 573.

19. Guthrie M., 1802. A tour, performed in the year 1795-6, through the Taurida, or Crimea, the ancient Kingdom of Bosphorus, the once-powerful Republic of Tauric Cherson, and all the other countries on the north shore of the Euxine, ceded to Russia by the peace of Kainardgi and Jassy. London, Nichols and son, 471.

20. Pellerin J. 1762. Recueil de médailles de rois. Paris, Guerin et Delatour, 278.

21. Meadows A., Purefoy P.B., Robinson E.S.G. 1972. Sylloge nummorum Graecorum. Vol. IV. Fitzwilliam Museum: Leake and General Collections. Pt. II. Sicily-Thrace. London, Oxford University Press, 38 .

\section{References}

1. Anokhin V.A. 1986. Monetnoye delo Bospora [Bosporus Coin]. Kiyev, Naukova dumka. 183.

2. Anokhin V.A. 1999. Istoriya Bospora Kimmeriyskogo [History of the Bosporus of Cimmeria]. Kiyev, Odigitriya. 240.

3. Anokhin V.A. 2011. Antichnyye monety Severnogo Prichernomor'ya [Antique coins of the Northern Black Sea]. Kiyev, Stilos. 328.

4. Moneta: 232-4473. URL: https://bosporan-kingdom.com/000-4770/1.html (date of the application: 10.08.2019)

5. Saprykin S.Yu. 1996. Pontiyskoye tsarstvo. Gosudarstvo grekov i varvarov v Prichernomor'ye [Pontic Kingdom. The state of the Greeks and barbarians in the Black Sea]. M., Nauka. 430.

6. Saprykin S.Yu. 2009. Religii i kul'ty Ponta ellinisticheskogo i rimskogo vremeni [Religions and cults of Pontus of Hellenistic and Roman times]. M., Tula, Triumf print. 430.

7. Frolova N.A. 1997a. Monetnoye delo Bospora (seredina I v. do n. e. - seredina IV v. n. e.). Ch. I. Monetnoye delo Bospora 49/48 gg. do n. e. $-210 / 211$ gg. n. e. [The coin business of the Bosporus (mid-1 st century B. C. - mid-4th century A. D.). Part I. The coin business of the Bosporus 49/48 years B. C. $-210 / 211$ years A. D.]. M., Editorial URSS. 448.

8. Frolova N.A. 1997b. Monetnoye delo Bospora (seredina I v. do n. e. - seredina IV v. n. e.). Ch. II. Monetnoye delo Bospora 211-341/341 gg. n. e. [The coin business of the Bosporus (mid-1st century B. C. - mid-4th century A.D.). Part II. The coin business of Bosporus 211-341/341 A. D.]. M., Editorial URSS. 536.

9. Frolova N.A. 2001. Bosporskiye monety vremeni pravleniya Asandra (49/48-21/20 gg. do n. e.) [Bosporus coins during the reign of Asander (49/48-21/20 B. C.).]. In: Trudy Gosudarstvennogo istoricheskogo muzeya. Vyp. 115. Numizmaticheskiy sbornik. CH. XIV. Numizmatika v Istoricheskom 
muzeye [Proceedings of the State Historical Museum. Vol. 115. Numismatic collection. Part XIV. Numismatics in the Historical Museum.]. M., GIM: 17-60.

10. Choref M.M. 2012. «Calamitas virtutis occasio», ili k istorii poslednikh let tsarstvovaniya Farnaka II [«Calamitas virtutis occasion», or the history of the last years of the reign of Farnak II]. In: Nauchnye vedomosti Belgorodskogo gosudarstvennogo universiteta [Scientific reports of Belgorod State University]. 7 (126). Vyp. 22: 44-59.

11. Choref M.M. 2014. K biografii Asandra: put' k prestolu [To the biography of Asander: the path to the throne]. In: Materialy po arhkeologii i istorii antichnogo i srednevekovogo Kryma. Vyp. 6: 456-487.

12. Choref M.M. 2016. K voprosu o deshifrovke monogramm na bosporskikh monetakh Mitridata V.I. Yevpatora Dionisa. In: Materialy po arhkeologii i istorii antichnogo i srednevekovogo Kryma [Materials on archeology and history of ancient and medieval Crimea]. Vyp. 8: 523-562.

13. Choref M.M. 2017. K istorii pravleniya arkhonta Gigienonta [To the history of the reign of Archon Hygienont]. In: Vestnik Nizhegorodskogo universiteta im. N.I. Lobachevskogo [Bulletin of the Nizhny Novgorod University name N.I. Lobachevsky]. 6: 62-72.

14. Babelon J. 1936a. Catalogue de la collection de Luynes. Monnaies grecques. Vol. IV. Syrie, Egypte, Cyrénaïque, Maurétanie, Zeugitane, Numidie. Paris, J. Florange, L. Ciani, 152.

15. Babelon J. 1936b. Catalogue de la collection de Luynes. Monnaies grecques. Vol. IV. Syrie, Egypte, Cyrénaïque, Maurétanie, Zeugitane, Numidie. Planches. Paris, J. Florange, L. Ciani, 76.

16. Cary F. 1752. Histoire des rois de Thrace et de ceux du Bosphore cimmérien éclaircie par les médailles. Paris, Ches Desaint \& Saillantm, 212.

17. de Callataÿ F. 1997. L'histoire des guerres mithridatiques vue par les monnaies. Publications d'Histoire de 1'Art et d'Archéologie de 1'Université Catholique de Louvan XCVIII. Numismatica Lovaniensia 18. Louvain-la-Neuve, Département d'Archéologie et d'Histoire de 1'Art, Séminaire de numismatique Marcel Hoc, 312.

18. Eckhel I. 1828. Doctrina numorum veterum. Vol. III. Continens Reliqvam Asiam Minorem, Et Regiones Deinceps In Ortvm Sitas. Pt. I. De numis urbium, populorum, regum. Vindobona: Sumptibus Friderici Volke, 573.

19. Guthrie M., 1802. A tour, performed in the year 1795-6, through the Taurida, or Crimea, the ancient Kingdom of Bosphorus, the once-powerful Republic of Tauric Cherson, and all the other countries on the north shore of the Euxine, ceded to Russia by the peace of Kainardgi and Jassy. London, Nichols and son, 471.

20. Pellerin J. 1762. Recueil de médailles de rois. Paris, Guerin et Delatour, 278.

21. Meadows A., Purefoy P.B., Robinson E.S.G. 1972. Sylloge nummorum Graecorum. Vol. IV. Fitzwilliam Museum: Leake and General Collections. Pt. II. Sicily-Thrace. London, Oxford University Press, 38 .

\section{Ссылка для цитирования статьи Link for article citation}

Чореф М.М. 2020. К истории изучения монетного дела царя Асандра. Via in tempore. История. Политология, 47(1): 21-29. DOI 10.18413/2687-0967-2020-47-1-21-29

Choref M.M. 2020. On the history of the study of the coinage of king Asander. Via in tempore. History and political science, 47(1): 21-29 (in Russian). DOI 10.18413/2687-0967-2020-47-1-21-29 